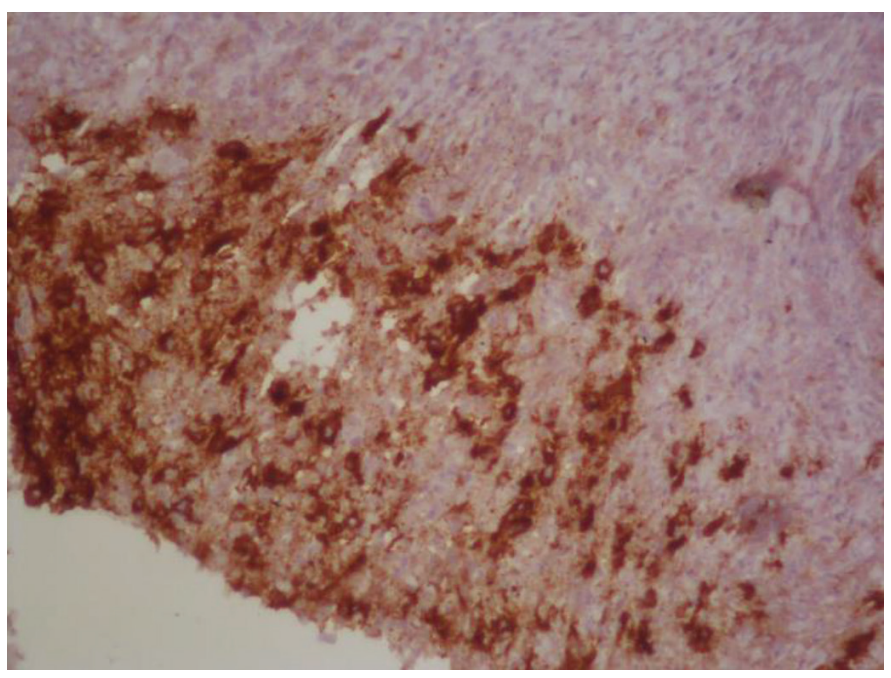

Figure 3. Bronchoscopic biopsy: Hodgkin lymphoma, CD30+.

Keywords: Hodgkin lymphoma, Cavitary lung lesions, Tuberculosis
Anahtar Sözcükler: Hodgkin lenfoma, Kaviter akciğer lezyonları, Tüberküloz

Informed Consent: It was received.

Conflict of Interest: The authors of this paper have no conflicts of interest, including specific financial interests, relationships, and/or affiliations relevant to the subject matter or materials included.

\section{References}

1. Grunzke $M$, Hayes $K$, Bourland W, Garrington T. Diffuse cavitary lung lesions. Pediatr Radiol 2010;40:215-218.

2. Bieliauskas S, Reyes-Trocchia A, Krasan GP, Main C, Trupiano JK. Hodgkin lymphoma presenting as multiple cavitary pulmonary nodules with associated mediastinal adenopathy and neck mass. J Pediatr Hematol Oncol 2009;31:730-733.

3. Yalçin B, Kutluk MT, Sanal O, Akyüz C, Anadol D, Cağlar M, Göçmen A, Büyükpamukçu $M$. Hodgkin's disease and ataxia telangiectasia with pulmonary cavities. Pediatr Pulmonol 2002;33:399-403.

\title{
Light Chain Myeloma with Highly Atypical Plasma Cells and Extensive Auer Rod-Like Inclusions
}

\author{
Yüksek Atipik Plazma Hücreleri ve Yaygın Auer Cisimciği Benzeri Innklüzyonları Olan Hafif \\ Zincir Myeloma
}

\author{
(D) Dietmar Enko1,2, (D) Gernot Kriegshäuser1,2 \\ ${ }_{1}^{1}$ General Hospital Steyr, Institute of Clinical Chemistry and Laboratory Medicine, Steyr, Austria \\ 2 Medical University Graz, Clinical Institute of Medical and Chemical Laboratory Diagnostics, Graz, Austria
}

To the Editor,

A 73-year-old woman with a history of chronic kidney disease presented with fever $\left(39.8^{\circ} \mathrm{C}\right)$, dyspnea, and fatigue. Complete blood count showed moderate normocytic anemia with hemoglobin of $10.0 \mathrm{~g} / \mathrm{dL}$ (normal range: 12.0-16.0), mild leukocytosis of 10.8×109/L (normal range: 4.0-9.0), and thrombocytopenia of 102×109/L (normal range: 150-400). Serum protein electrophoresis showed mild hypogammaglobulinemia of $6.7 \mathrm{~g} / \mathrm{L}$ (normal range: 7.0-16.0). Serum immunofixation electrophoresis electrophoresis demonstrated monoclonal $\kappa$-type light chains without heavy chain correlates $(\lg G, \lg M$, $\lg A, \lg D, \lg E)$. Moreover, a serum-free light chain assay measured a high $\kappa$-type light chain level of $2060.0 \mathrm{mg} / \mathrm{L}$ (normal range: 3.3-19.4) with a $\kappa / \lambda$ ratio of 48.5 (normal range: $0.3-1.7$ ).

A bone marrow aspirate smear showed $40 \%$ plasma cells, many of which appeared as binuclear plasmablastic cells with nucleoli ("owl-eyed" plasma cells), bright cytoplasm, and bundles of numerous Auer rod-like cytoplasmic inclusions (Figures $1 \mathrm{~A}$ and $1 \mathrm{~B})$. This unique morphology is remarkable. While the current literature describes Auer rod-like inclusions in single cases of different forms of myeloma $[1,2,3,4,5]$, this is, to the best of our knowledge, the first report on the concomitant appearance with enlarged highly atypical "owl-eyed" plasma cells in a patient suffering from $\kappa$-type light chain myeloma. 

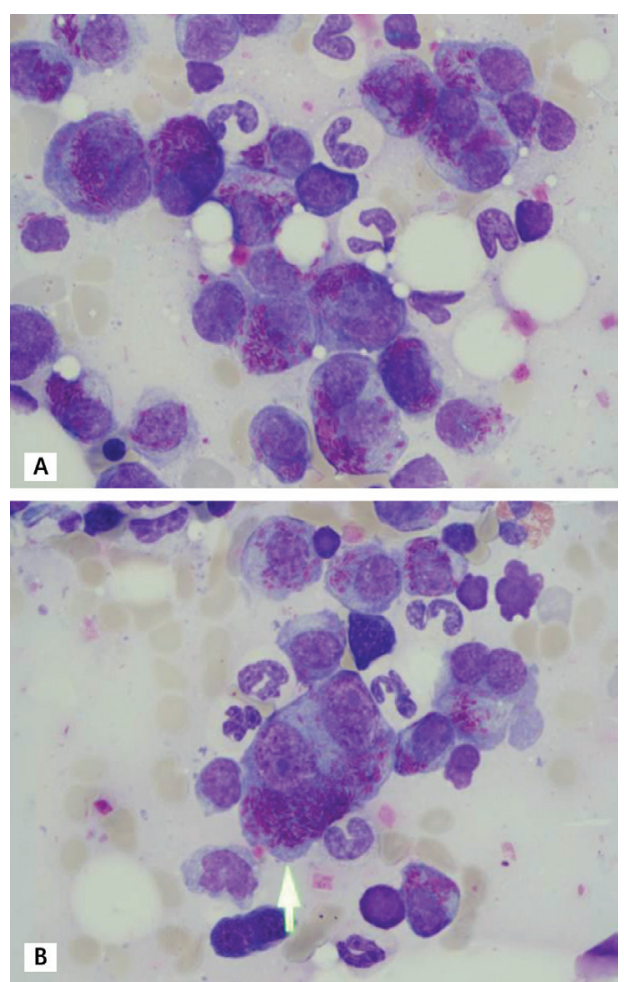

Figure 1. Bone marrow aspirate smear of a 73-year-old patient with $\kappa$-type light chain myeloma ( $A$ and $B$ ). The arrow marks a binuclear plasmablastic cell containing numerous Auer rod-like inclusions.
However, the prognostic value of this unusual plasma cell phenotype remains unclear.

Keywords: Light chain myeloma, Plasma cells, Bone marrow aspirate

Anahtar Sözcükler: Hafif zincir myeloma, Plazma hücreleri, Kemik iliği aspirasyonu

Informed Consent: Was obtained from the patient.

Conflict of Interest: The authors of this paper have no conflicts of interest, including specific financial interests, relationships, and/or affiliations relevant to the subject matter or materials included.

\section{References}

1. Castoldi G, Piva N, Tomasi P. Multiple myeloma with Auer-rod-like inclusions. Haematologica 1999;84:859-860.

2. Metzgeroth G, Back W, Maywald O, Schatz M, Willer A, Hehlmann R, Hastka J. Auer rod-like inclusions in multiple myeloma. Ann Hematol 2003;82:5760.

3. Abdulsalam AH, Al-Yassin FM. Myeloma cells with Auer rod-like inclusions. Turk J Hematol 2012;29:206.

4. Noujaim JC, D'Angelo G. Auer rod-like inclusions in $\mathrm{k}$ light chain myeloma. Blood 2013;122:2932.

5. Ho WK, Zantomio D. Auer rod-like inclusions in plasma cells in multiple myeloma. J Clin Pathol 2014;67:547-548.

๑Copyright 2019 by Turkish Society of Hematology

Turkish Journal of Hematology, Published by Galenos Publishing House

\title{
Aggressive Clinicopathological Course of Myeloma with $t(3 ; 16)$ (q21;q22) Cytogenetic Abnormality
}

\author{
t(3;16)(q21;q22) Anomalili Myeloma Olgusunda Agresif Klinikopatolojik Seyir
}

(D) Süreyya Bozkurt1, (D) Müfide Okay2, (D) Ibrahim Haznedaroğlu²

1istinye University Faculty of Medicine, Department of Medical Biology, İstanbul, Turkey

${ }^{2}$ Hacettepe University Faculty of Medicine, Department of Internal Medicine, Division of Hematology, Ankara, Turkey

To the Editor,

Multiple myeloma (MM) is a heterogeneous disease and patients present with a wide variety of cytogenetic anomalies reflecting the nature of the disease [1]. The aim of this letter is to report a rare karyotypic abnormality with an aggressive clinical course of MM.
A 56-year-old male patient was admitted to the neurosurgery clinic with dorsal shoulder pain and inability to walk in April 2011. He underwent thoracic and lumbar spinal magnetic resonance imaging. Laminectomy was performed on the patient upon detecting masses at the levels of the first and seventh thoracic vertebrae. The patient was referred to our center when he was determined to have "lymphoma" based on the first evaluation 